capitalist west, Moscow's imperial fantasies and its own village-centred, anti-modernist tendencies. Convincingly, the author suggests that the generation of the $1920 \mathrm{~s}$ still remains largely misunderstood. Their story was a more complicated and intriguing one, and theater played a key role in shaping a discourse around their concern with culture, politics, and identity. This is an elegantly written and entertaining book, with a well-crafted argument, and a timely focus on Ukraine's cultural diversity and identity politics.

MYROSLAV SHKANDRIJ University of Manitoba

\title{
Images of Rupture between East and West: The Perception of Auschwitz and Hiroshima in Eastern European Arts and Media. Ed. Urs Heftrich, Robert Jacobs, Bettina Kaibach, and Karoline Thaidigsmann. Heidelberg: Universitätsverlag Winter, 2016. 547 pp. Index. Photographs. Tables. €68.00, hard bound.
} doi: 10.1017/slr.2018.240

The volume under discussion is the result of a 2011 international interdisciplinary conference that took place in Heidelberg. The multitude of authors and topics present in the book reflects the scope of the conference and ambition of its organizers, who wanted "to map the perception of Auschwitz and Hiroshima in Eastern Europe in a comparative perspective" (11). And map they did, very extensively, forcing this reviewer to present only a short summary of the content of their excellent book. The unruly title of the volume reflects the most important aspects of the conference: the issue of representation of Hiroshima and the Holocaust and the question of the nature of these two catastrophes. The authors of the papers use both Auschwitz and Hiroshima not only as signs of the very materiality of these phenomena, but also to ponder their consequences that last until today.

Are Auschwitz and Hiroshima ruptures of civilization, the authors ask? Do they constitute a breach of civilization or its perverse continuity? Are they related? What was their impact on the cultures and politics of western and eastern Europe? How were they understood, and why were the western and eastern reactions so different? How were they presented in newspapers, poetry, prose, music, and film? These and other questions underlie each of the papers, including those devoted to a single event or artist. The main worry hovering over the volume is "the future genocidal potential opened up by these unprecedented instances of wholesale annihilation" (10). Searching to understand the nature and the consequences of Hiroshima and Auschwitz, several of the authors reach back to the writings of Hannah Arendt, Günther Anders, and Theodor Adorno, but most start with concrete texts, events or situations.

The first part of the book presents the American, German, and Japanese perspectives on both cases of mass annihilation; here I would like to single out the paper of Ran Zwigenberg, "The Hiroshima-Auschwitz Peace March and the Globalization of the "Moral Witness."” The paper is a fascinating instance of the archeology of today's ways of celebrating and mourning both events. The other papers in this section speak about Japanese-American writers on World War II (Bettina Hofmann), pacifism (Makiko Takemoto), and the feeling of victimhood that allowed the United States not to face its role as perpetrator (Robert Jacobs). Among many fascinating illustrations in the volume, I was struck by the reproduction of the cover of the 1948 Bantan edition of John Hersey's Hiroshima. It shows a typical American middle-class couple, the man supporting a desolate woman and looking back at a light indicating the destruction of 
their city (96). American readers were to feel themselves potential victims of nuclear terror.

The next sections discuss Soviet, Polish, Czechoslovak and Yugoslav reactions, each section very rich and diversified. We have chapters on Soviet (Christoph Garstka), Polish (Marlene Bainczyk-Crescentini), and Czech (Urs Herftrich) poetry about Hiroshima and Auschwitz; on prose writing and witnessing by Vasilii Grossman (Bettina Kaibach), Stanisław Lem (Karoline Thaidigsmann), Aleksandar Tišma (Vesna Cidilko), Ilija Jakovljević (Zrinka Božić Blanuša), David Albahari (Cristina Beretta), Tadeusz Borowski (Jiři Holý) and Czech political prisoners (Zuzana Jürgens). All these and other papers present each individual work in its larger context, making the volume a sort of reference book for the political and cultural history of how these calamities were used, and how these uses were resisted in literature or art. Chapters on the drawings of Zinovii Tolkaczev (Mirjam Rajner), on the visit of a Japanese girl in the Soviet youth center Artek (Renata von Maydell), on an unusual exhibit in the State Museum at Majdanek (Anna Ziębińska-Witek), and discussions of several films (Friederike Gürbig, Veronica Ambros, Oksana Bulgakowa) speak about the issues of representation and domestication of violence. Tvrtko Jakovina's paper is an overview of the attitudes towards the nuclear bomb in Tito's Yugoslavia, while Dragan Kujundžić looks at the ethical and philosophical definitions of the very terms Hiroshima and Holocaust.

The volume is movingly ended by the paper of Dorothea Redepenning on four western and one Japanese musical homages to the victims of Auschwitz and Hiroshima: Arnold Schoenberg's A Survivor from Warsaw, Krzysztof Penderecki's Threnody to the Victims of Hiroshima, Luigi Nono's Sul ponte di Hiroshima, Steve Reich's Different Trains, and Toshio Hosokawa's symphonic oratorio Voiceless Voice in Hiroshima. Though the chapters complement and enrich each other, they also stand on their own. The bibliographies attached to every paper will also be of great use. The book opens a lot of perspectives on issues that do not seem to ever fade away. As one of the epigraphs in the volume rightly quotes Emil Cioran: "Evil ... is both fascinating and contagious" (369). It is definitely important to read about it now.

IRENA GRUDZIŃSKA GROSS
Princeton University
Institute of Slavic Studies, Polish Academy of Science

Salki. By Wojciech Nowicki. Trans. Jan Pytalski. Rochester, NY: Open Letter, 2017. 228 pp. \$14.95, paper. doi: 10.1017/slr.2018.241

Wojciech Nowicki's Salki is an excellent, absorbing read, one that will bring an intellectually challenging pleasure to the general reader and a wealth of anthropological material to the Slavic specialist in a wide range of subfields, from Polish-Ukrainian relations and the culture of late Socialism to the study of borderlands, trauma, postmemory, and ethnic violence. I am offering this blunt, conclusive statement as my lead simply because it is too easy to dismiss titles that one assumes fall outside of a predefined area of interest, especially when the book's review is nestled among dozens of others in the back of an academic journal, and most especially when that same title is a single word that is unfamiliar in this usage to many native speakers of the book's original language. Salki, as Nowicki eventually explains, "are the rooms in an attic; they also use nyże, for places where you can store your memories and memorabilia right above your head. Just like those stories here, the salki of my memory, which 